\section{Respiratory Arousal Index}

Helga Peter

Marburg, Deutschland

\section{Synonyme}

RAI

\section{Definition}

Zahl der Arousal je Stunde Schlafzeit, die verursacht sind durch Apnoen, Hypopnoen und Respiratory Effort Related Arousals (RERAs).

Siehe auch $\triangleright$,Arousal“". 